\title{
E-MODULITY DEVELOPMENT EFFECTIVENESS DESCRIPTION TEXT FOR CLASS VII STUDENTS OF SMP
}

\author{
Afnita $^{1}$, A Amir ${ }^{2}$, tressyalina ${ }^{3}$ \\ \{afnita@fbs.unp.ac.id $\left.{ }^{1}\right\}$ \\ 1,2 Master Program Student, Universitas Negeri Padang, Indonesia \\ ${ }^{3}$ Faculty of language and Art, Universitas Negeri Padang, Padang Indonesia
}

\begin{abstract}
This study aims to describe the process of developing effective e-module text writing skills based on contextual teaching and learning (CTL). This type of research is research and development (research and development). The development model used is 4$\mathrm{D}$ (definition, design, development, and distribution). The subjects of this study were students of class VII2, 12 Padang Public Schools, totaling 25 people. Research data consists of quantitative data. Quantitative data were obtained from student learning outcomes in learning to write description texts. The results of this study indicate that $\mathrm{e}-$ learning modules write text description based on contextual teaching and learning (CTL) that results from effectiveness. This is evidenced from the results of the effectiveness of emodules. The effectiveness of e-modules consists of student learning activities and student performance test results. Student learning activities scored $90.05 \%$ with a very active category. The effectiveness of e-modules based on student performance test results on average the value obtained by students is 88,82 with the predicate A. Thus, the effectiveness of the development of e-module description text categorized as very active.
\end{abstract}

Keywords: effectiveness module electronic, text description, contextual teaching and learning

\section{Introduction}

The use of media and learning resources is part of the components that affect learning. Teaching materials need to be adapted to student conditions and learning strategies used by teachers. The use and empowerment of e-modules to support learning is a necessity, not only to improve the effectiveness and quality of learning, but more importantly is to increase the mastery of the material both teachers and students [1].

Facts in the field show that e-modules have a higher value compared to study groups that use source books. An online learning environment that allows students to explore information from various sources quickly and easily. This will encourage students to learn to be critical and selective in choosing existing information according to the problems given [2]. Based on this reality, it is important to develop e-modules based on Contextual teaching and learning (CTL) writing skills in the description text for grade VII students of Padang 12 Padang 12 important to do. Learning models that relate subject matter to the context of everyday life are certainly needed by students $[3,4,5,6]$. The development of e-module writing based on Contextual teaching and learning (CTL) is very appropriate, because writing activities require material that is close to the environment and the daily lives of students to be more attractive to 
students to write[7,8,9,10,11,12,13]. With the presentation of material and structured activity steps, students are expected to get concepts faster and be able to understand the contents of the description text well. This e-module is expected to provide a solution for students who have difficulty writing descriptive texts and to overcome the limitations of teacher learning resources. This e-module is also expected to develop students' creativity and innovation in learning [14-15].

Based on observations made by researchers at SMP 12 Padang on the learning process, it is found that there are still many teachers as instructors who use conventional methods and media in teaching teaching materials with printed modules, especially in the text description class VII in SMP 12 Padang. As a result of students learning to use conventional media in the form of printed modules and methods in the style of lecture to make the material presented.

The weakness is that if students are not equipped with modules that are not interesting from the material presented, the effect is students will have difficulty repeating the material in the learning process. The success of an educational goal depends on how the teaching and learning process experienced by students. A teacher besides being required to be careful in choosing and applying teaching methods in accordance with the objectives to be achieved, is also able to choose media that is in accordance with material to make it easier to deliver the material, for that we need media that can cause students' attractiveness in absorbing the material. One of the media that can be developed is an interactive learning module in the form of an electronic module (E-module) [16,17,18]. This school has used e-modules in terms of validity and practicality. However, it is not yet known in terms of effectiveness.

Based on this, we need an e-module development that can attract students to learn and facilitate students in learning. E-modules must be available that are appropriate in terms of material, presentation, language, and graphics. The making of e-modules aims to provide references in addition to textbooks distributed by the government. In addition, e-modules can be used by educators or teachers as a reference for creating new e-modules. This is done so that an effective e-module that is designed in accordance with the development of students, abilities, interests and needs, so that students are interested in writing.

\section{Research and Methods}

The development model used is a 4-D model. The product developed in this study is in the form of e-learning modules that are developed based on contextual teaching and learning. The 4-D development model consists of four stages of development, namely (a) defining, (b)designing, designing, (c) developing, and (e) disseminating.

The subjects of this effective e-module test were Grade VII students of SMP Negeri in Padang City. This research is limited in junior high schools that have used the revised edition 2013 curriculum. The school is Padang 12 Middle School. Data generated from quantitative trials. The instruments used consisted of interview sheets, student analysis questionnaires, curriculum analysis questionnaires, concept analysis questionnaires, e-module effectiveness and e-module distribution questionnaires. The data analysis technique used is descriptive data analysis by describing the effectiveness of the e-module of learning to write descriptive text based on contextual teaching and learning for grade VIII students of SMP N 12 Padang. From the results of the study were analyzed using descriptive statistics to get the average value and percentage as detailed information needed. Analysis of research data was carried out to determine effectiveness.

\section{Research Results and Discussion}




\section{a. The definition phase (Define)}

The defining stage consists of five steps, namely the initial initial analysis, student analysis, task analysis (curriculum analysis, concept analysis, and goal formulation). The initial initial analysis aims to bring up and establish the basic problems encountered in learning. Student analysis is a study of student characteristics which include abilities, background knowledge, and the level of cognitive development of students. Task analysis is a collection of descriptions to determine the content of teaching materials in the form of an outline. Task analysis includes content structure analysis, concept analysis, and formulation of learning objectives. Content structure analysis is a series of descriptions to identify curriculum compatibility with effective e-modules compiled. Concept analysis is a way to determine the material concepts needed for effective e-module preparation.

\subsection{Stage design (Design)}

The development of an effective e-module begins with searching for the various references needed. After that, do the outline design of the e-module, and design it so that it has an attractive appearance. The compilation of the e-module framework is adapted to contextual teaching and learning learning. The e-modules are designed based on theories about the structure of e-modules that are effective, namely the introduction, learning activities, and evaluation. The development of the learning activities section in the e-module is divided into two, learning activities 1 namely regarding aspects of knowledge, while learning activities 2 concerning aspects of skills.

\subsection{Development stage (Develop)}

The observed student activity consists of four aspects of observation. (a) Studying the instructions of the E-module, (b) constructivism, (c) inquiry, (d) asking questions, (e) learning community, (f) modeling, (g) Reflection, (h) taking the test writing description text.

The results of the analysis of the observation sheet of student activities showed that student learning activities using e-modules were categorized very active. It was seen from the acquisition of the average value of the overall percentage of student activity by $90.5 \%$ with a very active category. The method used to obtain these results is to sum the frequency of activities of each observation item contained in the observation sheet.

Based on this analysis, there are 7 activities that fall into the very active category. Statements that are categorized as very active are students' attention to learning by using emodules, studying the material in e-modules and doing things that are relevant to the learning material, discussing with friends proven by filling in discussion activities with modules, working on project assignments and exercises in e-modules, and make conclusions of learning material. The results of the analysis of the observation sheet of student learning activities studying e-modules writing description text can be seen in the following table.

Table 2. Analysis of Student Learning Activities When Using E-Learning Modules

\begin{tabular}{|l|l|l|l|l|}
\hline No & \multicolumn{1}{|c|}{ Statement } & $\begin{array}{l}\text { Frequency of } \\
\text { Activity }\end{array}$ & $\begin{array}{l}\text { Percentage } \\
\text { of Activity }\end{array}$ & categori \\
\hline 1 & Study the E-module instructions & 25 & 100 & Very active \\
\hline 2 & Constructivism & 23 & 92 & Very active \\
\hline 3 & Inquiry & 21 & 84 & Very active \\
\hline 4 & Asking & 22 & 88 & Very active \\
\hline 5 & Learning Society & 22 & 88 & Very active \\
\hline
\end{tabular}




\begin{tabular}{|l|l|l|l|l|}
\hline 6 & Modeling & 20 & 80 & Active \\
\hline 7 & Reflection & 23 & 92 & Very active \\
\hline 8 & $\begin{array}{l}\text { Take the test writing description } \\
\text { text. }\end{array}$ & 25 & 100 & Very active \\
\hline \multicolumn{2}{|c|}{ Total } & 182 & 724 & Very active \\
\hline \multicolumn{2}{|c|}{ Average } & & 90,5 & Very active \\
\hline
\end{tabular}

To see the difference in the percentage of student activities that study the description text using the e-learning module can also be seen through the following picture.

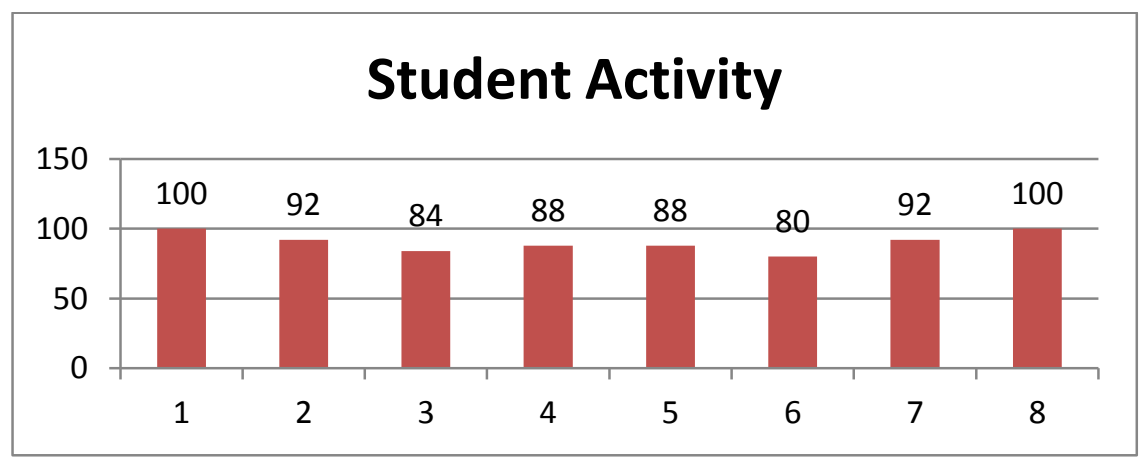

Figure 1. Histogram of Student Activities in Learning to Write Text Descriptions Using EModules

The effectiveness of e-modules is obtained from two sources, namely the results of tests of writing descriptive text performance, and attitude assessment. The description text knowledge test deals with basic competencies regarding analyzing the structure and linguistic characteristics of the description text. Five indicators were assessed, namely the definition of description text, the purpose of the description text, the structure of the description text, and the linguistic characteristics of the description text.

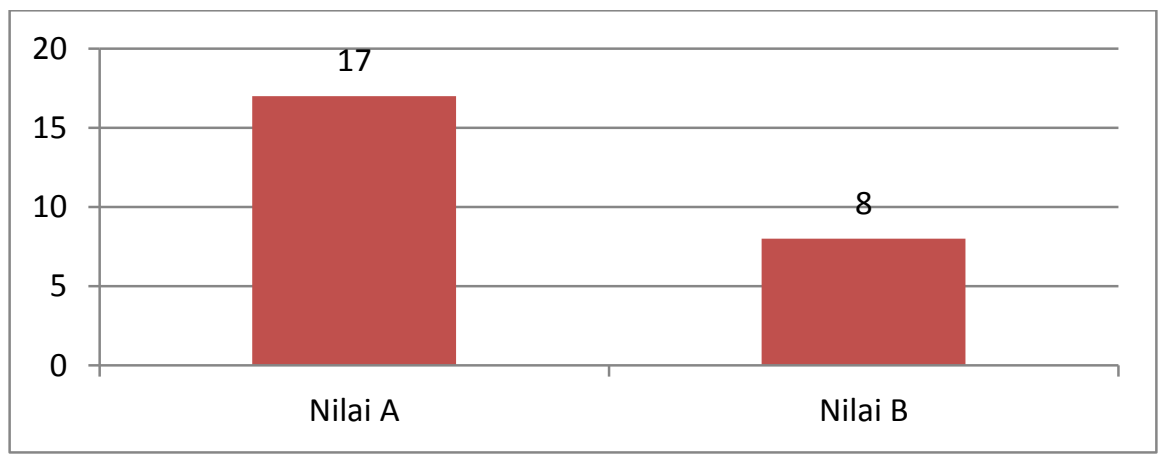

Figure 2. Knowledge Assessment Histogram Text Description

Overall the average value of knowledge obtained by students is $87.84 \%$ with the value of change A. So, it can be concluded that through the learning of text descriptions using e- 
modules, can effectively achieve student learning outcomes to meet the standards above KKM.

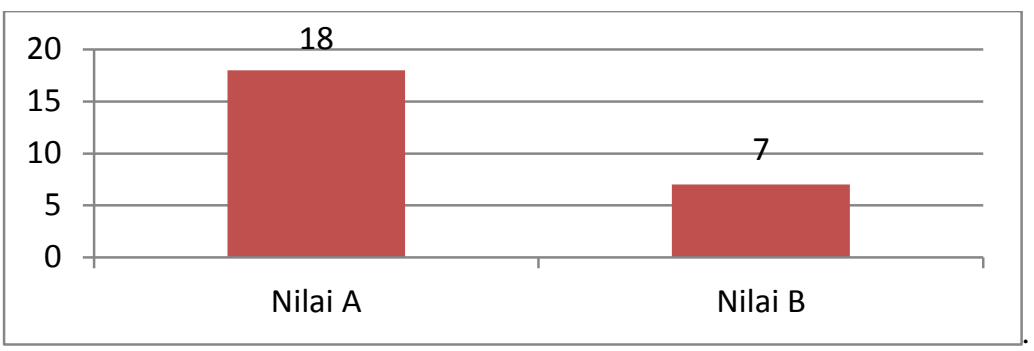

Figure 3. Histogram Assessment of Skills Tests

\subsection{Deployment Phase (Disseminate)}

The deployment stage is the final stage of the development process of e-learning modules for writing descriptive text based on contextual teaching and learning for Grade VII students of SMP N 12 Padang. The spread was carried out in accordance with the advice given by the collaborator teacher in the pilot class. Deployment of e-modules is done in two stages. The first stage is the distribution of e-modules on a limited basis to teachers other than collaborators in the pilot class, that is, teachers who teach in other classes. The teacher receives as many as one file or softcopy e-module given to the teacher. In addition, the teacher is also given a questionnaire about the distribution of e-modules. The second stage of distributing e-modules to students is done by distributing e-module files or softcopy as many students in the class.

\section{Conclusions}

Based on the results of the development that has been done, the following conclusions can be concluded. First, the e-module development process is in the defining stage. At this stage it was concluded that there were several problems that hindered the achievement of the learning objectives of writing descriptive text, namely the limitations of the teaching materials used. This has an impact on student learning outcomes that still have an average below the Minimum Mastery Criteria (KKM). Second, the process of developing e-modules at the design stage. At this stage the e-module framework is designed and the e-module draft is arranged. Planning the e-module learning framework consists of at least learning instructions, competencies to be achieved, the contents of the material, exercises, and worksheets. Third, the e-module development process is at the development stage (develop). At this stage, the emodules that have been made are then validated to see the validity of the e-modules. The effectiveness of e-module learning to write text descriptions based on contextual teaching and learning that was developed in the category It was evidenced from the results of the effectiveness of e-modules. Student learning activities scored $90.5 \%$ with a very active category. The effectiveness of e-modules based on student performance test results on average the value obtained by students is 88 with the title A. Fourth, the e-module development process is at the dissemination stage. Thus, the effectiveness of the development of the emodule text description for grade VII junior high school students is in the active category. 


\section{References}

[1] Ibrahim Mohamed Alfaki. (2015). University Students' English Writing Problems: Diagnosis and Remedy. International Journal of English Language Teaching. Published by European Centre for Research Training and Development UK (Www.eajournals.org), 3(3), 40-52.

[2] Buckingham, L. (2008). Development of English Academic Writing Competence by Turkish Scholars. International Journal of Doctoral Studies, 3(2002), 001-018. https://doi.org/10.28945/47

[3] Alodwan, T. A; Ibnian, S. S. (2014). The Effect of Using the Process Approach to Writing on Developing University Students' Essay Writing Skills in EFL Dr. Talal Abd Alhameed Alodwan 1 and Dr. Salem Saleh Khalaf Ibnian 2. International Journal of Linguistic and Communication, 2(2), 147-163.

[4] Chiramanee, T., \& Kulprasit, W. (2014). Journal Writing with Peer Feedback: A Friend or A Foe for EFL Learners. International Journal of English Language Education, 2(2), 142. https://doi.org/10.5296/ijele.v2i2.6038

[5] Muluneh, T. K. (2018). Improving Students' Paragraph Writing Skill through TaskBased Approach. Arts and Social Sciences Journal, 9(3). https://doi.org/10.4172/21516200.1000351

[6] Despande, S. (2014). Teaching Writing Skills in English: Involvement of Students in the Assessment and Correction of Their Own Errors. International Journal of English Language Teaching, 3(1), 68-73.

[7] Kurniawati, N.E dan Nuryatin, A. (2006). Developmen of Writing Description Text Modules, 5(1), 48-54.

[8] Lestari, C.D. Development of contextual Modules for Elementary school IPS Subjects. Jurnal Perspektif Ilmu Pendidikan. 30(3), 105-111.

[9] Y. Ning Su, CC Kao, CC Hsu, LCPan, SC Cheng, and YM Huang, "How Does Mozart's music Affectchildren's Reading? The Evidence From learning Anxietyand Reading Rates With E-Books. Educational Technology \& Societ y, vol.20, no. 2.pp.101-112, 2016.

[10] J. Wei Lin and HC Lin, 'User AcceptanceIn A Computer-Supported Collaborative Learning (CSCL) Environment with social network Awarenees (SNA) Support". Australasian Journal of Educational Technology, vol 35, no.1 2018.

[11] T. Doering, L. Pareira, L. Kuechler, and Amherst, "The Use of E-Textbooks In Higher Education: A Case Study, E-Leader Berlin, 2012.

[12] T. Jones and C. Brown, "Reading Engagement: A Comparison Between Tradisional and Ebooks print Books In An Elementary Classroom". International Journal of Intruction, vol 4, no.2. 2011

[13] Pawliczak, Jaana. (2015) Creative writing as a best way to improve writing skiils of students. Sino-Us English Teacing 2015, 12 (5)

[14] B. Plangsorn and S. Poopan, "Development of Prodycing and Using E-Books Competencies of Teachers In Chahhengsao", World Journal on Educational Tecnology, Current Issue, vol.09, no. 02, pp. 112-117, 2017

[15] B.Plangsorn and S. Poopan. "Development Of Producing and Using E-books Competencies Of Teachers In Chachengsao', Word Journal on Educational Tecnology, Current Issues, vol.09, 02, pp. 112-117, 2017.

[16] Sirikham A., \& Sae-Ear, Y. (2014). The development of low cost electronic books for the blind. international Journal of Information and Education Technology, (4) 4. 
[17] Trianto, Designing Innovative- Progressive learning model Jakarta: kencana 2012.

[18] Muslim, I. M. (2014). Helping EFL Students Improve their Writing. 4(2), 105-112. 